\title{
原子灭用黒鉛の製造について
}

東海電極製造株式会社 斎藤義平

\section{Production of Reactor grade Graphite}

\section{Yoshihira Saito}

(Tokai Electrode Mfg. Co.)

Production and Properties of reactor graphite are reported in details.

\section{1. 緒喜}

当社では昭和 29 年以来小規模に原子炉用黒鉛 の試作研究を続けてきたが，昭和 31 年 9 月原子 力平和利用試験研究費の受託を契機として, 原子 炉用黒鉊製造の主目標高高密度, 高純度, かつ異 方性の少ない製品の国産化に抢き名古屋工場，茅 ケ崎工場, 技術研究所の三事業所をあげて試作研 究を行なつた。

その結果一般特性においては外国品と同程度の 製品の工業的生産が可能の見透しが得られたので つぎにその製造法と得られた製品特性の一部を報 告する。

\section{2. 製造方法}

原子炉用黒鉛に対して要求される性質は, 高密 度，高純度，かつ異方性の少ないことである。ま ず第 1 の高密度黒鉛を製造するためには種々の条 件が考慮されるが特に原料コークスにカーボン・ ブラックを混入することおよびピッチ滲透をす る。第 2 の高純度黒鉛を製造するためには製造工 程中の硼素の污染を防止し, 黒鉛化時に高温化学 処理を行う。第 3 の異方性の少ない黒鉛の製造に は熱圧型込成形法を行引ことがもつとも適してい
ることを確認して試作研究に採用した。

以上の観点から製造方法は熱圧型込成形に重点 をおいて試作を行う一方，将来量産するためには 能率的な押出成形によらねばならない場合もある のでこれによる試作もあわせて実施した。

i) 原 料

多数の国産打よび輸入コークス，カーボン・ブ ラック，ピッチ等の原料についてクルクミン発色 分析法により硼素分を調査し Table 1 に示す原 料を選択使用した。

ii）製造方法

熱圧型込成形法による製造一一石油コークスを 一定の粒度に粉砕，穊分した後，予備試験により 得られたもつとも高密度を与える配合割合にした がつて石油コークスとカーボン・ブラックを混合 し，ついでピッチを加え $150 \sim 200^{\circ} \mathrm{C}$ で捏 合し た。つぎこの旺合物を型に入れ 水圧器で温度 $140 \sim 150^{\circ} \mathrm{C}$, 圧力 $500 \sim 700 \mathrm{~kg} / \mathrm{cm}^{2}$ で型込成形 を行なつた。かようにして得た成形品を原料と同 質の石油コークスを充填した焼成炉で燒成時間 $182 \mathrm{hrs}$ ，最高温度 $1,270^{\circ} \mathrm{C}$ で燒成した。焼成品 はさらに同質の石油コークスを充填した抵抗式電 気炉で $10,000 \sim 15,000 \mathrm{kwh} / \mathrm{t}$ の電力を用い最 高温度 $2,700 \sim 3,000^{\circ} \mathrm{C}$ で黒鉛化した。この際八

Table 1. Properties of Raw Materials

\begin{tabular}{l|c|c|c|c|c|c|c|c}
\hline \multirow{2}{*}{ Raw Material } & Source & $\begin{array}{l}\text { Volatile } \\
\text { matter } \\
(\%)\end{array}$ & $\begin{array}{l}\text { Fixed } \\
\text { Carbon } \\
(\%)\end{array}$ & $\begin{array}{l}\text { Ash } \\
(\%)\end{array}$ & $\begin{array}{c}\text { Boron } \\
(\mathrm{p} . \mathrm{p} . \mathrm{m})\end{array}$ & $\begin{array}{l}\text { Melting } \\
\text { Point } \\
\left({ }^{\circ} \mathrm{C}\right)\end{array}$ & $\begin{array}{l}\text { Free } \\
\text { Carbon } \\
(\%)\end{array}$ & $\begin{array}{l}\text { Particle } \\
\text { Size } \\
(\mathrm{m} \mu)\end{array}$ \\
\hline \multirow{2}{*}{ Coke } & Lockport & 0.68 & 98.83 & 0.43 & 0.3 & - & - \\
\hline Carbon Black & $\begin{array}{l}\text { Tokai Elect- } \\
\text { rode mfg. Co. }\end{array}$ & 1.56 & 98.0 & 0.02 & 0.4 & - & - \\
\hline Pitch & $\mathrm{A}(\mathrm{Japan})$ & 51.27 & 48.65 & 0.08 & 1.0 & 69 & 1.63 & $20 \sim 100$ \\
\hline
\end{tabular}


ロゲン系ガスを通じて脱灰および脱嗍素を行なつ た。

押出成形法による製造——原料には Table 1 に示したものを使用しまず石油コークスを粉砕， 分級し, コークス粒 40 部粉 60 部ピッチ 33 部 を配合して $130^{\circ} \mathrm{C}$ で捏合した。ついでこの捏合 物を水圧成形機で $150 \sim 200 \mathrm{~kg} / \mathrm{cm}^{2}$ の圧力で押 出成形した。このようにして得た成形品を既設焼 成炉に入れ最高温度 $1,000^{\circ} \mathrm{C}$ で焼成した。焼成 品は原料と同質のピッチを滲透して黒鉛化炉に入 れ原料と同質の石油コークスを充填して最高温度 $2,800^{\circ} \mathrm{C}$ で黒鉛化した。この場合は高温化学処理 を併用しなかつた。

\section{iii）製品寸法}

試作品の仕上り寸法は熱圧型込成形の場 合は $100 \times 100 \times 500 \mathrm{~m} / \mathrm{m}$ を押出成形の場合は $100 \times$ $100 \times 1,000 \mathrm{~m} / \mathrm{m}$ を標準にした。

\section{3. 研 究 結 棵}

i）高密度黒鉛にたいする結果 カーボン・ブラック混用の場合
原料コークスにカーボン・ブラックを混用する とカーボン・ブラックがコークス粒子間を充填し かつ加熱によりカーボン・ブラックの収縮作用の ため高密度黒鉛を得ることができる。その混用率 は石油コークスの種類および粒度，石炭ピッチの 種類が一定の場合はカーボン・ブラックの性質と くに粒子径により定まる。 $80 \mathrm{~m} \mu$ 程度のカーボ ン・ブラックを使用すると成形に適当な捏合物を 得るためにピッチを比較的多く要し $10 \%$ 以上混 用することは困難であり，かえつて製品の密度が 低くなる。10\%以下の場合は石油コークス 100 部にたいし，カーボン・ブラック 4 部の混用が最 大の密度, したがつて, 最小の気孔率を示すこと を明らかにしだ。この配合条件で得られた製品 (AG 2) の一般特性は Table 2 中に示すとおり である。これによると密度は 1.67 である。力 一ボン・ブラックの種類を変えて $300 \sim 400 \mathrm{~m} \mu$ 程度の粒径のものを混用して密度 1.73 以上のも のが得られているが，この詳細に関しては別の機 会に報告するつもりである。

ピッチ滲透による場合

Table 2. Properties of Reactor Graphite

\begin{tabular}{|c|c|c|c|c|c|c|c|c|c|}
\hline Graphite & & $\begin{array}{l}\text { Specific } \\
\text { Resistance } \\
\left(\mathrm{x} 10^{-4}\right. \\
\quad \Omega \mathrm{cm})\end{array}$ & $\begin{array}{l}\text { Flexural } \\
\text { Strength } \\
\left(\mathrm{kg} / \mathrm{cm}^{2}\right)\end{array}$ & $\begin{array}{c}\text { Apparent } \\
\text { Density } \\
(\mathrm{g} / \mathrm{cc})\end{array}$ & $\begin{array}{c}\text { Porosity } \\
(\%)\end{array}$ & $\begin{array}{c}\text { Coefficient } \\
\text { of Thermal } \\
\text { Expanion } \\
\left(\times 10^{-6} /{ }^{\circ} \mathrm{C}\right)\end{array}$ & $\begin{array}{c}\text { Elastic } \\
\text { modulus } \\
\left(\mathrm{kg} / \mathrm{mm}^{2}\right)\end{array}$ & $\begin{array}{l}\text { Ash } \\
(\%)\end{array}$ & $\begin{array}{l}\text { Boron } \\
\text { (p.p.m.) }\end{array}$ \\
\hline \multirow{3}{*}{$\mathrm{AG} 1$} & $\begin{array}{l}\text { Parallel to } \\
\text { grain }\end{array}$ & 6.6 & 276 & 1.65 & 25.0 & 1.33 & 1,031 & $0.05>$ & $0.5>$ \\
\hline & $\begin{array}{l}\text { Perpendicular } \\
\text { to grain }\end{array}$ & 9.1 & 145 & 一 & - & 3.10 & 464 & - & - \\
\hline & Ratio & 0.73 & 0.83 & 一 & - & 0.43 & 0.64 & - & 一 \\
\hline \multirow{3}{*}{$\mathrm{AG} 2$} & $\begin{array}{l}\text { Parallel to } \\
\text { grain }\end{array}$ & 12.5 & 161 & 1.67 & 22.7 & 2.61 & 一 & $0.01>$ & $0.1>$ \\
\hline & $\begin{array}{l}\text { Perpendicular } \\
\text { to Grain }\end{array}$ & 13.9 & 148 & - & - & 3.19 & - & - & - \\
\hline & Ratio & 0.90 & 0.92 & - & - & 0.82 & - & - & - \\
\hline \multirow{3}{*}{ AG 3} & $\begin{array}{l}\text { Parallel to } \\
\text { Grain }\end{array}$ & 10.5 & 260 & 1.72 & 21.6 & 2.57 & 665 & $0.01>$ & $0.1>$ \\
\hline & $\begin{array}{l}\text { Perpendicular } \\
\text { to Grain }\end{array}$ & 11.6 & 238 & - & - & 3.15 & 530 & - & - \\
\hline & Ratio & 0.91 & 0.92 & - & - & 0.82 & 0.80 & - & - \\
\hline \multirow{3}{*}{ AGOT } & $\begin{array}{l}\text { Parallel to } \\
\text { Grain }\end{array}$ & 7.6 & 147 & 1.70 & 24.0 & 1.44 & 1,050 & $0.07>$ & $0.5>$ \\
\hline & $\begin{array}{l}\text { Perpendicular } \\
\text { to Grain }\end{array}$ & 10.1 & - & - & 一 & 2.70 & 770 & - & - \\
\hline & Ratio & 0.75 & $一$ & - & - & 0.53 & 0.73 & - & 一 \\
\hline
\end{tabular}

AG 1: Extruded, Pitch Impregnated Stock

AG 2: Hot molded Stock

AG 3: Hot molded, Pitch Impregnated Stock

AGOT: Catalogue Value of National Carbon Co. 
Table 3. Effect of Pitch Impregnation on Properties of Graphite

\begin{tabular}{|c|c|c|c|c|c|c|c|}
\hline $\begin{array}{l}\text { Times of } \\
\text { Impregnation }\end{array}$ & & $\begin{array}{c}\text { Specific } \\
\text { Resitance } \\
\left(\times 10^{-4} \Omega \mathrm{cm}\right)\end{array}$ & $\begin{array}{l}\text { Flexural } \\
\text { Strength } \\
\left(\mathrm{kg} / \mathrm{cm}^{2}\right)\end{array}$ & $\begin{array}{l}\text { Apparent } \\
\text { Density } \\
(\mathrm{g} / \mathrm{cc})\end{array}$ & $\begin{array}{c}\text { Porosity } \\
(\%)\end{array}$ & $\begin{array}{l}\text { Coefficient } \\
\text { of Thermal } \\
\text { Expansion } \\
\left(\times 10^{-6} /{ }^{\circ} \mathrm{C}\right)\end{array}$ & $\begin{array}{l}\text { Elastic } \\
\text { Modulus } \\
\left(\mathrm{kg} / \mathrm{mm}^{2}\right)\end{array}$ \\
\hline \multirow{2}{*}{$\begin{array}{l}\text { Not } \\
\text { Impregnated }\end{array}$} & Parallel & 9.7 & 127 & 1.54 & 29.7 & 1.71 & 785 \\
\hline & Parpendicular & 13.8 & 89 & - & - & 3.38 & 456 \\
\hline \multirow{2}{*}{$\begin{array}{l}1 \text { Time of } \\
\text { Impregnation }\end{array}$} & Parallel & 8.1 & 166 & 1.64 & 25.2 & 1.58 & 1,301 \\
\hline & Parpendicular & 11.6 & 128 & - & - & 3.29 & 605 \\
\hline \multirow{2}{*}{$\begin{array}{l}2 \text { Times of } \\
\text { Impregnation }\end{array}$} & Parallel & 9.2 & 208 & 1.71 & 21.6 & 1.63 & 1,087 \\
\hline & Parpendicular & 9.9 & 153 & - & - & 3.17 & 654 \\
\hline \multirow{2}{*}{$\begin{array}{l}3 \text { Times of } \\
\text { Impregnation }\end{array}$} & Parallel & $6: 0$ & 223 & 1.77 & 19.0 & 1.44 & 1.127 \\
\hline & Parpendicular & 9.0 & 176 & - & - & 3.27 & 687 \\
\hline
\end{tabular}

黑鉛の気孔をピッチを滲透，焼成することより 充填して高密度黒鉛の製造に関する基礎研究結果 は当社の三谷，土肥2) 等が発表しているが，原子 炉用黒鉛の原料に使用したロックポートコークス についてピッチ渗透を繰返した場合の密度の向上 ならびにその他の特性変化の一例を Table 3 に 示す。これから判るとおりロックポート・コーク スは加熱による収縮が比較的小さいために，得ら れた黒鉛化品の密度は比較的低い，したがつて滲 透による密度の増加は大きく滲透 1 回目は 0.1 程 度 2 回目，3回目は $0.06 \sim 0.07$ 程度向上してい る。試作で得られた製品（AG 1) の平均特性は Table 2 中に示すと打りである。また熱死型达 成形品 (AG 2) をピッチ滲透した製品（AG 3) は密度が 1 回滲透で 0.05 程度向上し Table 2 中に示すとおり 1.72 のものが得られた。

ii）高純度黒鉛に対する結果

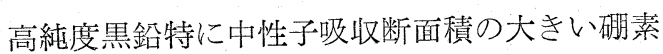
の含有量の極めて少ない黑鉛を製造するために， 製造工程中の硼素の挙動に関して基礎調査を行な いその結果を 32 年 1 月に行なわれた第 1 回原子 カシンポジゥム゙拈よび東海技報いに発表した。 この結果にもとつき，製造工程中の硼素污染に とくに注意して中間工業的規模で試作した結果 Table 2 中に示すとおりガス脱灰等の特殊処理 を施さなくとも灭分 $0.05 \%$ 以下硼素 0.5 p.p.m. 以下の製品が得られた。このものは反射材として 十分使用できるものと思われる。

また，ハロゲン系ガスによる中間工業的規模の
高温化学処理て Table 2 中に示もとおり，黒鉛 中の灰分は $0.01 \%$ 以下硼素は 0.1 p.p.m. 以下 に激減させることができ，減速材として優透な特 性をもつ高純度黒鉛の製造法を確立した。

iii）異方性が少ない黑鉛に対する結果

Table 2 からわかるとおり, 押出成形品の電気 抵抗，曲げ強さ，熱膨脹係数の方向比は試作品でも 比較のために Table 2 に揭げた National Carbon Co. のカタログに示された AGOT 品でも 0.4〜 0.8 であるが，熱圧型込成形により製造された製 品のそれは $0.8 \sim 0.95$ で極めて異方性が少なく， 原子两用黒鉛としてもつとも優れた性能をもつこ とがわかる。かように熱圧型达成形品が方向性が 少ないのは成形圧力が比較的に低いからコークス 粒子が層状に並ぶことが少ないためと思われる。

\section{4. 結論}

31 年度原子力平和利用研究補助金を受託して 原子炉用黑鉛の試作研究を行なつた結果, 高密度 の点では $80 \mathrm{~m} \mu$ 程度の粒径のカーボン・ブラッ クをコークス 100 部に対し 4 部混用することによ り密度 1.67 のものが得られ，さらにピッチ滲透 することにより 1.72 の原子炉黒鉛として適当と 思われる密度の製品が得られた。

高純度の点では嗍素の污染を防止して製造する ことにより反射材級の製品が得られ，さらにハロ ゲン系ガスで高温化学処理をすることにより灰分 $0.01 \%$ 以下硼素 0.1 p.p.m. 以下の減速材級の 製品が得られた。 
また方向性の少ない点では熱圧型込成形法によ

り方向比 0.8 以上の製品が得られ，原子炉用黒鉛 の製造目標を達成し，一般特性においては外国品 に劣らない原子炉用黒鉛の工業的生産の可能の見 透しが得られた。

本試作品の中性子特性に関しては測定依頼中で あり今後発表できることと思われる。

\section{交献}

（1）高吉・桜井，第 1 回政府育成原子力技術発表会 昭和 32 年 3 月 26 日

技術部・東海電極技報，18，1．31，(1957）

（2）三谷・土肥，炭素，6；38，(1957)

(3) 斎藤・山口, 第 1 回原子力カジンポジウム, 昭 和 32 年 1 月 15 日

（4）斎藤・山口，東海電極技報，18，1.3，(1957）

\section{崖素製品の沿革 (化学便覧, 永井雅夫より)}

工業材料としての炭素は登場して約 150 年にな り，新しい材料としてつぎつきに採用されて有効 な役目を果して来た。耐火性電導材として，電 極, 電刷子,アーク・カーボン。化学的に安定な 材料としては, 単体または複合体の形で耐蝕材料 として急速に伸びつつある。固体潤滑性は機械用 摺動材料，超耐火性は窯業材料として実用されて 来た。最近ではその核的特性を活用して原子炉の 減速材，反射材として大型原子炉には不可欠な材 料となつた。こうした用途はまた炭素の特性の究
明，炭素製品の進歩を促して，超純度の形に於 て, あるいは他の物質との複合体として，その機 能を向上してきた。かくて炭素材料は金属材料, 非金属材料，あるいは有機材料の領域に進出し て，それらの達成し得なかつた機能を発揮し，将 来ますますその進歩発展が期待されているもので ある。

炭素製品の各用途別に最初に工業化された年代 は次の通りである。

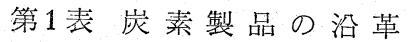

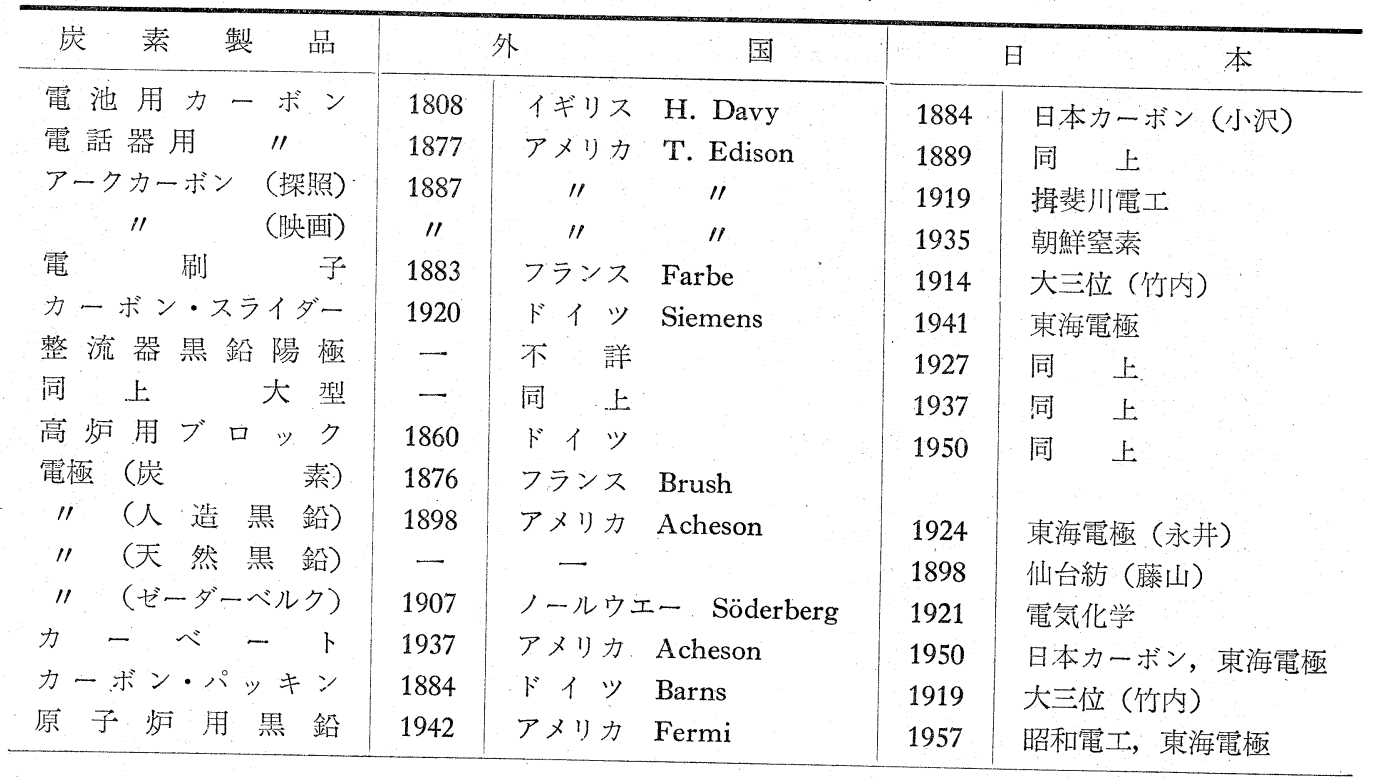

日本に㧍いて現在 (1957) これらの炭素製品の年生産総額は約 100 億を超えている。 